\title{
THE 1926 AMENDMENT OF THE MARCH CONSTITUTION AS AN EXAMPLE OF RIVALRY BETWEEN THE SEJM AND SENATE
}

\author{
Tomasz Litwin \\ Jesuit University Ignatianum in Kraków, Department of Contemporary Political Systems \\ e-mail: tomasz.litwin@gmail.com
}

\begin{abstract}
In 1926, the March Constitution from 1921 was amended, one of the elements of this process was rivalry between the Sejm and Senate. It was caused by the attempts of Senate to equalize its position with the Sejm, personal rivalry between the marshals of both chambers and imprecise rules of the Constitution concerning its amendment. The rivalry between both chambers resulted in their weakening and strengthening of the executive power controlled by "Sanacja".
\end{abstract}

Keywords: Sejm, Senate, amendment, March Constitution, August Amendment, voting

\section{INTRODUCTORY REMARKS}

One of the basic characteristics of the procedure of amending the constitution in Poland that differs it from the procedure of the enactment of ordinary bills is the strengthening the position of Senate. The Senate is able to effectively block any draft of the bill amending the constitution that is not accepted by the appropriate majority of the senators. This prerogative of Senate has existed between the First and Second World War and also in the period from 1989, when the Senate was reestablished, until now. However, only once, in 1926, it led to a strong political conflict between the two chambers of the Polish parliament. The conflict concerned adoption of the bill amending the Constitution from 1921 (March Constitution) which after its enactment has been commonly known as the August Amendment.

The aim of this article is to present and explain the reasons, the course and the effects of the mentioned conflict with the use of legal-institutional and interpretive approaches, including legal-dogmatic, logical-language, teleological, systematic and legal historical research methods in the interpretation of the legal rules. The 
sources, such as documents, diaries, newspapers and scientific literature will be subjected to critical analysis. The article is an attempt to prove the following research hypothesis: the main causes of the conflict between the Sejm and Senate were (1) unbalanced position of the two parliamentary chambers motivating the Senate to improve its position, (2) imprecise rules of the March Constitution concerning the procedure of its amendment, especially participation of the Senate in the procedure, (3) personal rivalry between Marshal of the Sejm Maciej Rataj and Marshal of the Senate Wojciech Trąmpczyński.

\section{THE POSITION OF THE SEJM AND SENATE IN THE MARCH CONSTITUTION}

The analysis of the provisions of the March Constitution leads to the conclusion that the Sejm had stronger position than the Senate. Such conclusion concerns all the major parliamentary functions: legislative, control and electoral.

All drafts of the bills were submitted to the Sejm. A group of deputies had the right to introduce drafts of the bills including the drafts of the bills amending the constitution. The Senate or a group of senators did not have such a right. The Senate could introduce the amendments to the draft of the bill, however, the Sejm could reject such amendments by the 11/20 majority vote. If the majority in the Sejm supporting rejection of Senate's amendments was lesser than $11 / 20$, the draft of the bill failed. The Senate could also reject the whole draft. In political practice, the Senate gained the right of absolute veto towards drafts of the bills adopted by the Sejm, although this right was used only a few times. The Senate was also limited by defined period of time (60 days) for decision concerning the introduction of the amendments or rejection of the whole draft of the bill adopted by the Sejm. If the Senate exceeded such period there was a legal assumption that the draft of the bill was adopted according to the wording enacted by the Sejm ${ }^{1}$.

The Council of Ministers and particular ministers were politically responsible only before the Sejm. The Sejm could also execute the legal responsibility of the ministers and accuse a minister before the Tribunal of State. The President could also be accused before the Tribunal (constitutional responsibility) only by the Sejm. Moreover, the Sejm could constitute an investigative committee ${ }^{2}$.

The President was elected by the National Assembly composed of deputies and senators. However, according to the rules of the March Constitution, the deputies were four times more numerous than senators, who could be easily outvoted by the deputies ${ }^{3}$. The Sejm elected eight members of the Tribunal of State and Senate - only four ${ }^{4}$.

1 Article 10, Article 35 and Article 125 of the March Constitution. The English translation of the March Constitution is available at: http://libr.sejm.gov.pl/tek01/txt/kpol/e1921.html

2 Article 34, Article 51 and Article 58 and Article 59 of the March Constitution.

3 Article 36 and Article 39 of the March Constitution.

4 Article 64 of the March Constitution. 


\section{THE INSTITUTIONAL-LEGAL ANALYSIS OF THE RIVALRY BETWEEN THE SEJM AND SENATE IN THE PROCESS OF AMENDING THE MARCH CONSTITUTION}

The March Constitution in its Article 125 described the procedure of amending the constitution. The two first paragraphs of this article stated that a quarter of the legal number of deputies could introduce the motion to amend the constitution. By the way of legal practice the government also received the right to introduce such a motion justified by the right of the Council of Ministers to introduce drafts of ordinary bills. From the present perspective, such an argument seems to be unacceptable because the procedure of adopting amendments of the constitution differs from the procedure of adopting ordinary bills in the number of the subjects that are entitled to introduce such amendments. According to Article 125, paragraph 2, the motion concerning the amendment of the constitution should be published within 15 days. This rule obliges the Marshal to inform the Sejm that the draft of amendment of the constitution was introduced to the Sejm. It also seems to mean that the debate in the Sejm on such a draft could be conducted at earliest after 15 days following presentation of that information by the Marshal. This ensured the possibility of scrupulous preparation of the position for every political party and did not allow too rapid adoption of such a draft. The adoption of the draft of the bill amending the constitution in the Sejm required support by the majority of two-thirds of the deputies in the presence of at least a half of the legal number of the deputies. The same requirements of majority and quorum also concerned the Senate. Therefore, the Senate could effectively reject the draft of the bill amending the constitution [Komarnicki 1922] not only in a situation when the majority of senators did not support the amendment, but also when the majority of senators supporting it was lesser than the required two-thirds in the presence of the appropriate quorum.

Unfortunately, the described procedure was not precisely regulated and brought controversies concerning participation of Senate, especially the scope of amendments introduced by the Senate to the bill adopted by the Sejm. This was one of the elements of rivalry between the two chambers which took place in the summer of 1926 and resulted in the adoption of the August Amendment. The Senate introduced to the draft of the bill amendments considerably broadening the scope of the draft adopted by the Sejm. The supporters of such a right of the Senate stated that Article 125, paragraph 1 of the March Constitution established equal rights for the both parliamentary chambers in the procedure of amending the constitution. The only privilege of the Sejm in that procedure was the right to introduce a draft of the bill amending the Constitution by the quarter of the legal number of the deputies, whereas senators did not have such a right at all. However, the Constitution did not limit the right of the Senate to modify the draft of the bill, especially in the way that was directly referring to the drafts of the bills introduced to the Sejm. This argument was raised by the senators in the summer of 1926 when 
they discussed the draft of the bill amending the constitution adopted by the Senate. They stated that all the Senate's amendments were previously considered by the Sejm, since their substance was covered by the motions introduced to the Sejm. If the constitutional legislator intended to limit the scope of amendments, it would enact appropriate constitutional regulations. The opponents of such an approach stated that the legally accepted knowledge of chambers about each other's activities should be based only on what was officially communicated. Such a source of knowledge could only be the official correspondence between the Marshal of the Sejm and Marshal of the Senate and not, for example, the newspapers. In the legislative procedure, the Marshal of the Sejm delivers to the Senate only the draft of the bill adopted by the Sejm, so the Senate is bound by the text of such a draft and its scope and not by the motions that were considered by the Sejm. Therefore, Senate's amendments that are beyond of the scope of the substance of the bill fail automatically ex lege [Rataj 1965; Senate's 135 sitting, 1926].

However, the introduction of Senate's amendments to the draft of the bill amending the Constitution adopted by the Sejm brings doubts. Article 125, paragraphs 1-2 does not allow to exclude such a possibility. If in such a situation Senate's amendment should be considered as legally acceptable, how should the Sejm further proceed over this kind of draft? There are few solutions. The Sejm could again vote on the whole draft of the bill, i.e. such a vote would concern the rules that were adopted by both chambers and also the rules that were amended by the Senate. Alternatively, the Sejm could vote only on the rules amended by the Senate and the fragments of the bill draft text that were agreeably adopted by both chambers could be treated as an adopted bill that only requires the promulgation by the president to come into the force. It seems that the latter position should be regarded as right. Otherwise, the right to initiate proceedings introducing the draft of the bill amending the constitution would de facto belong to the Senate, not to the Sejm.

Another doubt concerns the method of Sejm's consideration of such a draft of the bill amended by the Senate. One position, supported by Maciej Rataj (Marshal of the Sejm 1922-1928) in parliamentary practice, required the majority of two-thirds in the presence of a half of legal number of the deputies to accept the Senate's amendment. If the amendment did not receive the required support, the relevant fragment of the draft of the bill would be nullified (therefore, the Sejm could not reject the amendment of the Senate). During the debate on Senate's amendments to the draft of the bill amending constitution in 1926 (August Amendment) [Sejm's 299 sitting, 1926], a deputy, Kazimierz Bagiński, proposed to either adopt or reject Senate's amendments by the majority of two-thirds. Another position was presented by Kazimierz Świtalski (Marshal of the Sejm, 1930-1935) who postulated that Senate's amendments should be considered in accordance to Article 35 of the March Constitution, i.e. they could be adopted by the simple majority or rejected by the 11/20 majority in the presence of the one-third of the legal number of deputies [Sejm's 142 sitting, 1935]. The position presented by Rataj should be considered as right. One of the basic characteristics of the procedure 
amending the constitution is generally accepted requirement of higher majority necessary to adopt such a type of bills as compared to the majority required for adoption of ordinary bills. According to Article 125, paragraph 1 of the March Constitution, the support in both chambers by the appropriate majority with the appropriate quorum is a sine qua non condition for adoption the bill amending the constitution. Therefore, the adoption by the Sejm of Senate's amendments by the simple majority with the quorum of one-third of the legal number of deputies would actually be against Article 125, paragraph 1 of the March Constitution which requires that draft of the bill amending the constitution should be supported by at least a majority of two-thirds in the presence of at least a half of the legal number of the members in both chambers, not in one. Even stronger criticism should be placed on a situation when Senate's amendments would be rejected by the 11/20 majority in the presence of at least one-third of the legal number of deputies. In a such situation, draft of the bill can be regarded as being de facto adopted only by the Sejm without participation of the Senate. This would be directly against Article 125 of the March Constitution. The rejection of Senate's amendments by a two-thirds majority in the Sejm should be interpreted similarly: such a bill would be de facto adopted only by the Sejm and not by both chambers.

Because of the lack of detailed rules in the March Constitution, the analysis of this mode of constitutional amendments leads to the conclusion that it could be used to partially amend the constitution as well as to replace it by a new constitutional act.

In the political practice, this mode of amending the constitution was used twice: partial amendment of the constitution in 1926 (August Amendment) and replacement of March Constitution by new constitution (April Constitution) in 1935.

The process of adoption of the August Amendment is an attractive basis for the analysis of the relations between the Sejm and Senate. It should be regarded as an interesting case study of the rivalry of both parliamentarian chambers. Unfortunately, the volume limits of this article do not allow to present in detail the whole legislative process. However, it should be mentioned that the conflict between the chambers concerned mainly two articles of the proposed amendment of the March Constitution: the right of self-dissolution of the parliament as well as the executive orders of the president and the mode of its repeal. The first issue concerned the majority necessary for adoption of the resolution on self-dissolution of the parliament. In the Sejm, this kind of resolution required support of a threefifths majority in the presence of at least a half of the legal number of deputies and in the Senate, it required support of a two-thirds majority in the presence of at least three-fifths of the legal number of senators. The second issue concerned the way of repealing the executive orders of the president, a procedure which could be made only by the Sejm's resolution. The draft of the bill amending the constitution adopted by the Sejm and delivered to the Senate was composed of ten articles. Eight of them had substantial character and the last two had procedural character [Sejm's 292 and 297 sittings, 1926]. 
In the Senate, some articles were adopted without any amendments: the first article (introduction of the "budgetary year"), the second article (the sanction of mandate loss for a parliamentarian who received benefits because of his/her economic relations with the government), the seventh article (voting on vote of no confidence for the government or minister at the next sitting of the Sejm after the sitting when it was introduced at earliest) and articles ninth and tenth which had procedural character. Other rules were modified to the lesser or larger degree, like Article 5 which was deeply amended. This rule concerned the procedure of adoption of the ordinary bills, however, it was later rejected by the Sejm and failed. The Senate also amended other articles. These amendments mainly equalized the competences of both chambers. The amendments of Article 3 (procedure of the adoption of the budget) had generally editorial character and were agreed by special reconciliation committee composed of deputies and senators [Rataj 1965]. In the next article, concerning dissolution of the parliament, the Senate amended its third paragraph. According to the amendment, both chambers of the parliament could adopt the resolution on its dissolution and such resolution could be adopted by a three-fifths majority in the presence of at least a half of the legal number of deputies/senators. The amendment to the sixth article allowed to repeal the presidential executive order not only by the Sejm's resolution but also by the Senate's resolution. The eighth article (possibility to amend the constitution by third term Sejm elected according to the principles of the March Constitution without Senate participation) was not supported by the appropriate majority of senators and was rejected [Rataj 1965; Senate's 135 and 136 sittings, 1926].

The Senate also adopted the amendments to other provisions of the March Constitution, which were not amended by the draft of the bill adopted by the Sejm. Article 1a retained the Sejm's right to initiate the legislative procedure concerning draft of the bill but it also enabled the Council of Minister to introduce the draft of the bill to either the Sejm or the Senate, with the exception of financial bills which should be introduced to the Sejm ["Czas" 1926; Sejm's 299 sitting, 1926; Article 10, Sejm's print No. 2472, 1926]. The Senate also introduced a new Article 5a which enabled the Senate to constitute inquiry commissions [Sejm's 299 sitting, 1926]. The Senate also adopted other new Articles 6a-6d which forbid to grant amnesty to the ministers accused by one of the chambers, required the acceptance of both chambers to conclude some international agreements, declare war and conclusion of peace and enabled to execute the legal responsibility of president and members of the Council of the Ministers by both chambers [Czajowski 1999; Kulesza 2006; Sejm's 299 sitting, 1926].

The draft of the bill was next delivered to the Sejm and was considered by it on August 2, 1926 during its 299 sitting. The Sejm was voting only those articles that were amended by the Senate and on those provisions that were introduced by the Senate. The Sejm enacted Article 3 with Senate's amendments and rejected Article 4, paragraph 3 and Article 5 amended by the Senate, as well as all new provisions introduced and adopted only by the Senate. 
The rejection of the amended Article 4, paragraph 3 had a very important and negative impact on both parliamentary chambers. It meant, as it turned out later, the loss of parliament's right for self-dissolution. According to Rataj, it was the effect of voting of left-wing deputies against this rule, resulting from "anti-Senate momentum" of the left [Rataj 1965]. However, Andrzej Ajnenkiel suggested that it was also a result of purposeful activity of a part of right-wing deputies who were afraid of self-dissolution of the parliament and unfavorable results of subsequent elections [Ajnenkiel 1972].

The most intense political dispute between the chambers concerned Article 6 of the draft. The adoption of this rule was regarded as very important politically, because it enabled the President to edit executive orders. The failure of enactment of this provision could lead to a very serious political conflict between the parliament and the government. According to the Senate's amendment, such executive orders should be delivered not only to the Sejm but also to the Senate and could be repealed by the resolution of any of the chambers. In editorial terms, these Senate amendments were made by introducing in appropriate places "and the Senate" and "or by the Senate". However, the Senate adopted not the amendments, but the whole new Article 6 of the draft. Rataj who analyzed this situation in his diaries regarded it as "political blackmail" towards the Sejm. Rataj, who regarded senators Wojciech Trąmpczyński (Marshal of the Senate) and Józef Buzek as the main inspirers of such Senate tactics, thought that both senators calculated that the Sejm would be afraid to reject the whole article because this would mean lack of entitlement for the President to edit executive orders and a probable serious political conflict with the government, for which introduction of President's right to edit executive orders was the main condition to initiate changes in the political-legal system. Such position was confirmed by Trąmpczyński who in declaration attached to the Senate's resolution emphasized that the resolution with the Senate's amendments to the draft of the bill amending the constitution could be considered only on the basis of Article 125 of the March Constitution and Article 35 cannot be used in this procedure. According to this declaration, the draft of the bill amending the constitution required a two-thirds majority vote for adoption. Each chamber had the right to reject the provision adopted by the other chamber, however, it meant the failure of such provision. Trąmpczyński also stated that this procedure concerned the whole Article 6 and its rejection meant also the lack of the possibility to enact the authorization bill for the government, and its enactment was a vital issue for the government. Marshal of Sejm Rataj felt offended by such sort of "blackmail", so he decided "to teach Trąmpczyński a lesson". He used previously created practice, that was also accepted by the Senate, according to which, the Sejm could divide the text of Senate's amendment and then adopt one part of amendment and reject the other part. He decided that the part of Article 6 in the Senate's version that was repeating the content of Article 6 enacted by the Sejm was adopted by the appropriate qualified majority vote in both chambers. Therefore, Rataj conducted the voting in the Sejm only on the new terms added by the Senate: "and the Senate" and "or by the 
Senate". The Sejm rejected these Senate's amendments. Although Trąmpczyński was protesting against such practice and presented his opinion to Rataj, President and Prime Minister, the bill amending the March Constitution - generally known as the August Amendment - came into force according to the wording enacted by the Sejm during its 299 sitting [Rataj 1965].

\section{THE PERSONAL RIVALRY BETWEEN RATAJ AND TRĄMPCZYŃSKI}

The personal relations between Marshal of the Sejm Maciej Rataj and Marshal of the Senate Wojciech Trąmpczyński seem to be a very complicated issue. In his diaries, Rataj stated that he had a lot of respect for Trąmpczyński because of his age, function and political past and expressed that respect when they were meeting. In his inaugural speech, as the Marshal of the Sejm, Rataj even thanked Trąmpczyński for his past activities describing him as "wise" and "experienced" [Rataj 1965; Rataj 1987]. It should also be mentioned that elections of Rataj and Trąmpczyński for the positions of Marshal of Sejm and Marshal of Senate, respectively, were one of the elements of the coalition agreement between right-wing parties supporting Trąmpczyński and PSL "Piast" supporting Rataj [Kaczmarek 1993; Kołodziejczyk 1991]. However, Rataj also regarded Trąmpczyński as a very touchy person, who sometimes did not behave seriously and who could not realize his political ambitions because of a weak political position of the Senate and its Marshal. The conflicts between Rataj and Trąmpczyński occurred even before 1926 and mainly concerned the procedure of Sejm's consideration of Senate's amendments, rejection by the Senate of the drafts of bills adopted by the Sejm, as well as Rataj's control and management of Sejm and Senate Office. Rataj's control over the Office meant that Senate expenditures were dependent on the will of the Marshal of the Sejm [Kaczmarek 1993]. When the draft of the bill amending the constitution was considered by the Senate, Rataj in his diaries accused Trąmpczyński of being completely unable to conduct any sort of political negotiations or to make any kind of the political compromise. Even though Rataj presented himself as a supporter of strengthening Senate's position, he was conscious that left-wing deputies with their anti-Senate approach will block every legal proposition that will equalize the rights of both chambers ${ }^{5}$. As previously mentioned, Rataj also accused Trąmpczyński of some kind of political "blackmail" when the Senate adopted the whole new version of Article 6 instead of making appropriate amendments. The reaction of Rataj, when he wanted "to teach Trąmpczyński a lesson", also seems very personal [Rataj 1965].

Rataj's opinions concerning Trąmpczyński seem to be neutral and fair. It seems that because of Trąmpczyński's approach, the Senate did not gain any additional

5 However, Zygmunt Kaczmarek describes Rataj as the opponent of the strengthening of Senate's position [Kaczmarek 1993]. 
competences apart from those provided by the draft of the bill amending the constitution, primarily adopted by the Sejm. All "forced" attempts to strengthen the Senate must have met with rejection in the Sejm, especially since left-wing parties in the Sejm represented by the sufficient number of deputies to block the attempts to amend the Constitution, had a negative approach towards the institution of Senate. It is difficult to presume that Trąmpczyński did not know about that and still his political tactics turned out to be totally ineffective. Moreover, it even harmed the Senate's interests, because the Sejm's version of the bill amending the Constitution which allowed the Senate to independently cause dissolution of the parliament by a two-thirds majority vote in the presence of three-fifths of the legal number of senators, strengthened the position of the Senate comparing to the rules of the March Constitution. Article 26 of the Constitution required for the dissolution of the parliament adoption by the Senate of the appropriate bill by the majority of threefifths of the legal number of the senators. The Senate could adopt such a resolution only if the President first introduced the appropriate motion. Trąmpczyński also rejected Rataj's compromise proposal that the repealing of presidential executive orders shall be done by adoption of the appropriate bill which meant that the Senate would have a real influence on that procedure. What is more, if the negotiations between Sejm and Senate representatives were conducted more wisely, they could create a chance for the Senate to gain some further competences.

However, it also seems that the conflict between Rataj and Trąmpczyński had also a strong negative influence on the behavior of the Marshal of the Sejm. His intention to take revenge on Trąmpczyński and the Senate led to the situation in which both the Sejm and Senate lost the right to cause self-dissolution of the parliament. It seems that Rataj was mainly responsible for that because before the voting he did not convince the left-wing deputies of the necessity of supporting the Senate's amendment. He was also accused of being very nervous and making many mistakes when presiding the crucial sitting during which the Sejm voted over the draft of the bill that returned from the Senate. As a result, he allowed the parliament to lose the right for self-dissolution [Kołodziejczyk 1991]. From the perspective of a supporter of defending the rights and position of the Sejm, Rataj could be criticized because if he "chopped" Article 6, paragraph 3 he should do the same with Article 4, paragraph 3. This rule wording adopted by the Senate was such:

President of the Republic of Poland dissolves the Sejm and Senate before the passing of the period for which they were elected on the basis of the resolution of the Sejm or Senate adopted by a three-fifths majority vote in the presence of a half of the legal number of deputies or senators [Sejm's 295 sitting, 1926; Senate's 136 sitting, 1926].

If the terms "or the Senate" and "or Senators" were excluded from this text, it would be part of the rule that was adopted in an appropriate mode by both chambers. After adoption of this rule in such wording it could be assumed that because of the adoption of the new version of Article 26, the President had the right to dissolve the parliament after the appropriate motion of the Council of the 
Ministers and adoption of the appropriate resolution by the Sejm. Rataj was also criticized because he could otherwise interpret the result of voting, retaining the parliament's right for self-dissolution [Lewin 1933].

\section{THE EFFECTS OF THE RIVALRY BETWEEN THE SEJM AND SENATE}

The political analysis of the presented events leads to the conclusion that the process of adoption of the August Amendment was strongly influenced by the conflict and rivalry between the Sejm and the Senate. It seems that the main cause of this conflict was an attempt of the Senate to strengthen its political-legal position, not supported by the Sejm. Such an attempt resulted from a much weaker position of the Senate comparing to the Sejm according to the rules of the March Constitution. Other source of this conflict was definitely the personal ambitions of Marshal of the Senate, Wojciech Trąmpczyński.

The main losers in the conflict between the chambers were Trąmpczyński and the Senate. The only relative success of Senate was rejection of Article 8 of the draft of the bill adopted by the Sejm. This rule in certain conditions provided the possibility of third term Sejm elected according to the rules of the March Constitution to amend the constitution independently, without participation of the Senate. The presence of left-wing majority in such Sejm would cause a real danger of the abolition of Senate. However, the Senate, like the Sejm, lost the right for self-dissolution and the Marshal of the Senate was mainly responsible for that because of his inability to make any kind of compromise.

The August Amendment can also be largely regarded as the Sejm's loss. In spite of Sejm's attempts, it did not adjust Article 35 to the practice that established quasi absolute veto of the Senate. Also the Sejm and its Marshal were mainly responsible for the loss of the right for self-dissolution of the parliament, weakening its position [Kaczmarek 1993].

The August novelty was, therefore, a major success of the government and the whole dominating right-wing political group, "Sanacja". The President gained two important rights - the right to edit executive orders with the same power as bills and the right to dissolve the parliament. It should also be added that because of the ineptitude of the parliament, President Ignacy Mościcki, who had strong connections with "Sanacja", gained an exclusive right to dissolve the parliament before the end of the parliamentary term of office. Therefore, "Sanacja" could decide about the date of the elections and set it at the best political moment. Although the President did not have the right to veto the bills, it should be emphasized that he was not obliged to promulgate an enacted draft of the bill in a precisely described period. He also had the right to close the parliamentary session and to dissolve the parliament. Therefore, "Sanacja" cooperating with the President and the government could block every inconvenient draft of the bill and gain control over the legislative process. 
Tytul: Zmiana Konstytucji marcowej z 1926 r. jako przykład rywalizacji Sejmu i Senatu

Streszczenie: W roku 1926 doszło do zmiany Konstytucji z 1921 r., jednym z elementów tego procesu była rywalizacja pomiędzy Sejmem a Senatem. Doszło do niej w związku z próbami Senatu zrównoważenia swojej pozycji względem Sejmu, rywalizacją personalną marszałków obu izb oraz nieprecyzyjnymi przepisami Konstytucji z 1921 r. dotyczącymi jej zmiany. Rywalizacja obu izb zakończyła się ich osłabieniem i wzmocnieniem egzekutywy kontrolowanej przez „Sanację”.

Słowa kluczowe: Sejm, Senat, poprawka, Konstytucja marcowa, nowela sierpniowa, głosowanie

\section{REFERENCES}

\section{Literature}

1. Ajnenkiel, A., 1972, Spór o model parlamentaryzmu polskiego do roku 1926, Książka i Wiedza, Warszawa.

2. Czajowski, J., 1999, Senat Rzeczypospolitej Polskiej pierwszej kadencji 1922-1927. Pozycja prawnokonstytucyjna i praktyka ustrojowa, Wydawnictwo Sejmowe, Warszawa.

3. „Czas” z dnia 2 sierpnia 1926 r., 174, 3.

4. Kaczmarek, Z., 1993, Wojciech Trąmpczyński, Lega, Poznań.

5. Kołodziejczyk, A., 1991, Maciej Rataj 1884-1940, Wydawnictwo Sejmowe, Warszawa.

6. Komarnicki, W., 1922, Polskie prawo polityczne (geneza i system), Księgarnia F. Hoesicka, Warszawa.

7. Kulesza, W.T., 2006, Nowela sierpniowa z 1926 r., „Przegląd Sejmowy”, 4 (75), pp. 9-48.

8. Lewin, I., 1933, Prawo rozwiazywania cial ustawodawczych. Studjum z prawa konstytucyjnego, Księgarnia „Oświata” Lwów.

9. Rataj, M., 1965, Pamiętniki 1918-1927, Ludowa Spółdzielnia Wydawnicza, Warszawa.

10. Rataj, M., 1987, Wskazania obywatelskie i polityczne. Wybór pism i przemówień z lat 19191938, Ludowa Spółdzielnia Wydawnicza, Warszawa.

\section{Legal acts}

1. Ustawa z dnia 17 marca 1921 r. - Konstytucja Rzeczypospolitej Polskiej - Dz.U. RP Nr 44, poz. 267.

2. Ustawa z dnia 2 sierpnia 1926 r. - zmieniająca i uzupełniająca Konstytucję Rzeczypospolitej z dnia 17 marca 1921 r. - Dz.U. RP Nr 78, poz. 442.

3. Ustawa konstytucyjna z dnia 23 kwietnia 1935 r. - Dz.U. RP Nr 30, poz. 227.

\section{Documents}

1. Druk Sejmowy nr 2472, 1926 r., Zakład Drukarski Wacława Piekarniaka, Warszawa.

2. Sprawozdanie stenograficzne z 135 posiedzenia Senatu Rzeczypospolitej Polskiej z 30 lipca 1926 r., Zakład Drukarski Wacława Piekarniaka, Warszawa.

3. Sprawozdanie stenograficzne z 136 posiedzenia Senatu Rzeczypospolitej Polskiej z 31 lipca 1926 r., Zakład Drukarski Wacława Piekarniaka, Warszawa. 
4. Sprawozdanie stenograficzne z 292 posiedzenia Sejmu Rzeczypospolitej Polskiej z 16 lipca 1926 r., Zakład Drukarski Wacława Piekarniaka, Warszawa.

5. Sprawozdanie stenograficzne z 297 posiedzenia Sejmu Rzeczypospolitej Polskiej z 22 lipca 1926 r., Zakład Drukarski Wacława Piekarniaka, Warszawa.

6. Sprawozdanie stenograficzne z 299 posiedzenia Sejmu Rzeczypospolitej Polskiej z 2 sierpnia 1926 r., Zakład Drukarski Wacława Piekarniaka, Warszawa.

7. Sprawozdanie stenograficzne z 142 posiedzenia Sejmu Rzeczypospolitej Polskiej z 23/24 marca 1935 r., Zakład Drukarski Wacława Piekarniaka, Warszawa. 